\title{
A Study of Generalized Horizon View Camera
}

\author{
Liwen Gong Non-member (Gifu University, kon@yam.info.gifu-u.ac.jp) \\ Kazuhiko Yamamoto Member (Gifu University, yamamoto@info.gifu-u.ac.jp) \\ Kunihito Kato Non-member (Gifu University, kkato@info.gifu-u.ac.jp)
}

Keywords : horizon view camera, single camera, object detection, distance measurement

Recently, person and object detection methods using a single camera have been proposed in many fields. However, there is a problem that detecting image includes objects and regions corresponding to ground. Therefore, it is necessary to separate target objects from the ground. To solve this problem, various methods are proposed to detect them. However some methods don't have high accuracy.

The Horizon View Camera (HVC) had proposed as one of the solution to solve these problems. HVC put a single camera on the ground, and the optical axis of the camera is set on the horizon by a mirror. The HVC system is shown in Fig 1(a). HVC can obtain two kinds of images is shown in Fig 1(c). The lower half of the image is only objects on the ground in front of the HVC. The other half is in front of the HVC. The lower of the image obtained by the HVC includes objects on the ground without including the ground. Therefore, HVC is possible to detect object easily.

But the HVC system has a problem that has a narrow view, and the degree of freedom of the camera settings is not high. Then, we improve the degree of freedom of camera settings of HVC by using the horizon that exists at the center of camera lens, and propose Generalized Horizon View Camera (GHVC) that can observe wider view.

HVC system set the optical axis of the camera directed to the horizon. In the world coordinate system, Z-axis is defined as pointing towards front; $\mathrm{X}$-axis is pointing to right; and Y-axis is pointing up. As shown in Fig 2, when the camera rotates to $\alpha=\theta_{d}$ on X-axis, if the center of camera lens is put on the horizon, the horizon line always through the pin-hole of camera and project to the image-formation side even if the camera rotates. The reflected image by the GHVC system also contains objects on the ground without including the ground. So we can get a large degree of freedom in camera settings and viewing angle. We set center of camera lens on the ground by using a mirror. The GHVC system is shown in Fig 1(b).Fig 1(d) shows an example of image obtained from GHVC. To observe the broad outlook, we adjusted the angle of the camera, and used the reflection image as the entire image.

When the GHVC system moves forward, the emission point of the image is located on the center of horizon line in the image, and if distance between the camera and the object is short, the object moves greatly in the image. On the other hand, the distance is long, the object does not move so much. By using this difference, we can measure the distance by the direction and the size of each movement vector to the object.

We experimented measuring the distance to objects using the GHVC and the HVC. In the situation of a single background, we set two objects which have flat surface at the same distance on the ground. The camera was moved forward by a constant distance each time, and an image was taken at each distance. The distance between the camera and objects changed from $34 \mathrm{~cm}$ to $18 \mathrm{~cm}$ by a $2 \mathrm{~cm}$ step. The experimental result is shown in table 1 , we obtained the measuring distance by the GHVC was detected correctly than the HVC.

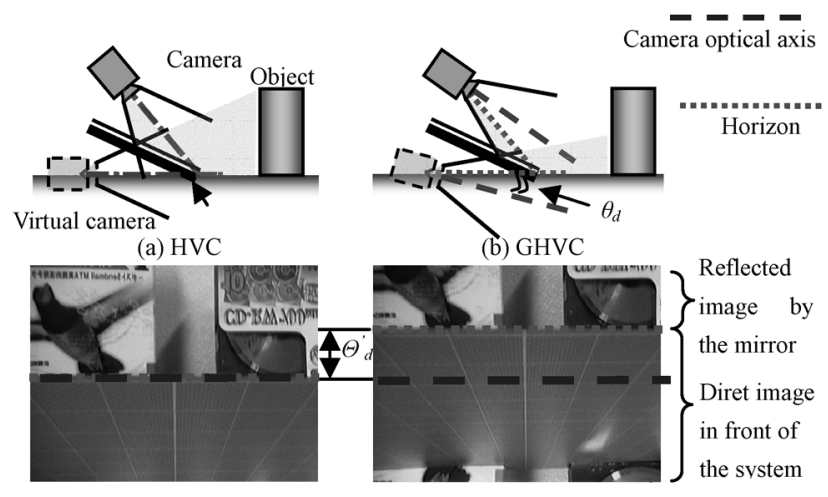

$\begin{array}{ll}\text { (c) Image from the HVC } & \text { (d) Image from the generalized HVC }\end{array}$

Fig. 1. Generalizing HVC and HVC

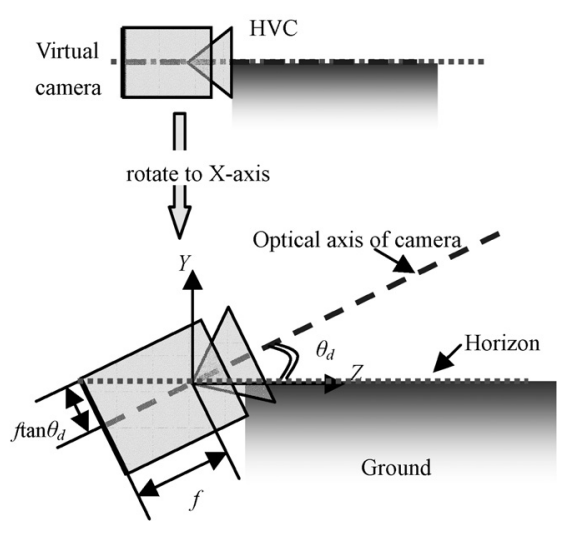

Fig. 2. Position of horizon in image

Table 1. Average error of distance measurement

\begin{tabular}{|c|c|c|c|c|c|c|c|c|c|}
\hline Actual distance & $34 \mathrm{~cm}$ & $32 \mathrm{~cm}$ & $30 \mathrm{~cm}$ & $28 \mathrm{~cm}$ & $26 \mathrm{~cm}$ & $24 \mathrm{~cm}$ & $22 \mathrm{~cm}$ & $20 \mathrm{~cm}$ & $18 \mathrm{~cm}$ \\
\hline Detected distance by GHVC & $33.09 \mathrm{~cm}$ & $31.89 \mathrm{~cm}$ & $30.66 \mathrm{~cm}$ & $28.56 \mathrm{~cm}$ & $26.61 \mathrm{~cm}$ & $24.79 \mathrm{~cm}$ & $22.61 \mathrm{~cm}$ & $21.12 \mathrm{~cm}$ & $19.02 \mathrm{~cm}$ \\
\hline Average error(GHVC) & $2.25 \mathrm{~cm}$ & $2.43 \mathrm{~cm}$ & $2.41 \mathrm{~cm}$ & $1.90 \mathrm{~cm}$ & $2.07 \mathrm{~cm}$ & $2.13 \mathrm{~cm}$ & $2.03 \mathrm{~cm}$ & $2.01 \mathrm{~cm}$ & $2.02 \mathrm{~cm}$ \\
\hline Detected distance by HVC & $32.07 \mathrm{~cm}$ & $29.37 \mathrm{~cm}$ & $28.12 \mathrm{~cm}$ & $27.79 \mathrm{~cm}$ & $25.01 \mathrm{~cm}$ & $22.86 \mathrm{~cm}$ & $22.08 \mathrm{~cm}$ & $20.37 \mathrm{~cm}$ & $17.62 \mathrm{~cm}$ \\
\hline Average error(HVC) & $2.92 \mathrm{~cm}$ & $3.28 \mathrm{~cm}$ & $2.93 \mathrm{~cm}$ & $2.50 \mathrm{~cm}$ & $2.96 \mathrm{~cm}$ & $2.01 \mathrm{~cm}$ & $2.40 \mathrm{~cm}$ & $2.18 \mathrm{~cm}$ & $2.18 \mathrm{~cm}$ \\
\hline
\end{tabular}




\title{
一般化 Horizon View Camera の考察
}

\author{
非会員 宮 立文* 正 員 山本 和彦* \\ 非会員 加藤 邦人*
}

\section{A Study of Generalized Horizon View Camera}

Liwen Gong*, Non-member, Kazuhiko Yamamoto*, Member, Kunihito Kato*, Non-member

\begin{abstract}
In this paper, we described various properties of a Generalized Horizon View Camera (GHVC).Original Horizon View Camera (HVC) is a optical system composed of a camera and a mirror. HVC put a single camera on the ground, and the optical axis of the camera is set on the horizon by a mirror. HVC can obtain two kinds of images. One is the image including only objects on the ground in front of the HVC. The other image is including just in front of the HVC. Therefore, it is possible to detect object easily. The GHVC is able to improve a degree of freedom of HVC. In this experiment, we measured a distance to an object by the GHVC. We confirmed that detecting object using the GHVC was effective.
\end{abstract}

キーワード : Horizon View Camera, 単眼カメラ, 物体検出, 距離計測

Keywords : horizon view camera, single camera, object detection, distance measurement

\section{1. はじめに}

単眼カメラを用いた人物や物体の検出では，オクルージ ヨンなどの問題により，カメラを目的とする物体等の上方 に設置し，見下ろすようにして得られた画像を用い，その 位置を計測する研究が多くみられる。その研究範囲は，人 物検出や, ロボットのための状況理解, 自動車事故の防止 のための歩行者や車両等の検出など広い分野で行われてい $ろ^{(1) \sim(5)}$ 。

しかしこれらにおいて，物体を検出する際に用いる画像 には地面領域が含まれており，目的の物体を検出するため に地面領域から地面以外の領域を区別する必要がある(1)(2)。 またさらに検出した物体の中から対象領域を抽出する必要 がある。例えば人物検出では，人物らしい領域を検索して 人物を発見する方法 ${ }^{(3)(4)}$ や，人物が移動していることを利用 した移動量からの検出方法(5)などが提案されている。これら 物体等を検出するために, 様々な解決法が提案されてきた が，確実に物体等を検出するのは困難である。

これまでに，単眼カメラを用いた障害物などの物体を検 出する方法として, システムの小型化が可能な, Horizon View Camera（以下 HVC）が提案されている ${ }^{(6) \sim(8)}$ 。

しかし，従来の HVC はカメラの光軸を鏡によって地平線 上を走らせるため, 画像のうちの半分しか使えなく, また

\footnotetext{
岐阜大学 工学部

干501-1193 岐阜県岐阜市柳戸 1-1

Faculty of Engineering, Gifu University 1-1, Yanagido, Gifu-shi, Gifu 501-1193
}

視野が狭いという欠点がある。そこでカメラ光軸ではなく カメラレンズの中心を地平線上に置くことで, 従来の HVC のカメラ配置の自由度を高め, より広い視野を観測できる 一般化 Horizon View Camera (以下一般化 HVC) を提案する。 また一般化 HVC は従来の HVC の特徵を保つことができ, システムが前後移動することによって取得された 2 種類の 連続画像を用いた多様な動画像処理等が可能である。

本稿では，一般化 HVC の構成や一般化 HVC が持つ特性 について述べ, その特性を用いて物体検出を行い, 一般化 HVC が物体検出において有効なシステムであることを示 す。

\section{Horizon View Camera の概要}

単眼カメラでの位置計測では，一般的に物体は地面に垂 直に立っているものと考えて, 得られた物体領域の足の座 標值とカメラ情報を用いて物体の位置を計測する。しかし, この物体の位置計測法では, 物体領域の抽出を正確に行え ない場合は，精度の高い位置計測は不可能である。つまり 精度の高い物体検出を行うには, 高い精度での地面領域と 物体領域の分離が可能な方法が必要である。

これらの問題を解決するに, カメラを地面に設置し, カ メラ光軸が地平線上を通るようにしたカメラシステム Horizon View Camera が提案されている(6)。この HVC を用い ることによって, 地面を含まない地上の物体のみの画像が 得られる。そのため HVCでは地面上の物体抽出することが 容易となり，物体検出を高い精度で行うことができる。ま 
た物体検出を行う必要すらないという利点を持つ。さらに システムを前進移動させることで, HVC の性質を利用して, 物体までの距離計測を容易にすることが可能となる。

カメラの光軸が地平線を通るようにするには, カメラを 地面に半分埋める必要があるが，これは実現不可能である。 そこで鏡を用いて, カメラの光軸が地面上を通るようにシ ステムを設計する(6)。HVC システムを図 2(a)に示す。HVC から得られた画像を図 2(c)に示す。得られた画像のうち, 半 分は鏡の反射により得られた画像で, 残りの半分は鏡の前 方の画像である。この 2 つの境界が地平線となる。

\section{3. 一般化 HVC の提案}

〈3・1〉地平線の特徵従来の HVC はカメラ光軸を鏡 の角度の 2 倍にする必要があり, 実際に距離計測を行う場 合, 画像のうちの半分しか利用されておらず，視野が狭い。 そこで，広い視野を持つシステムを構築するため，カメラ レンズ中心と同じ高さに存在する地平線を利用することと した。これによって, HVC の自由度を高め, 普通のカメラ でも広い視野を観測することが可能となる。

地平線はカメラの回転に依存せずに, いつもカメラレン ズ中心と同じ高さに存在する。従来の HVCでは鏡を用いて カメラの半分を地面に埋め込み, カメラ光軸が地平線上を 通るようにしている。ここで世界座標系の $Z$ 軸は前方向へ, $X$ 軸は右, そして $Y$ 軸は上方向と指定する。カメラレンズの 中心を中心とし, カメラを回転させた場合, ピンホールカ メラであれば，画像座標系と世界座標系の関係は(1)式を満 たす。

$$
m=P R M
$$
ここで

$$
\begin{aligned}
& m=\left(\begin{array}{l}
x \\
y \\
1
\end{array}\right), P=\left(\begin{array}{lll}
f & 0 & 0 \\
0 & f & 0 \\
0 & 0 & 1
\end{array}\right), M=\left(\begin{array}{l}
X \\
Y \\
Z
\end{array}\right) \\
& R=\left(\begin{array}{lll}
R_{11} & R_{12} & R_{13} \\
R_{21} & R_{22} & R_{23} \\
R_{31} & R_{32} & R_{33}
\end{array}\right) \\
& R_{11}=\cos \beta \cos \gamma, \quad R_{12}=\cos \beta \sin \gamma, R_{13}=-\sin \beta \\
& R_{21}=\sin \alpha \sin \beta \cos \gamma-\cos \alpha \sin \gamma \\
& R_{22}=\sin \alpha \sin \beta \sin \gamma+\cos \alpha \cos \gamma, R_{23}=\sin \alpha \cos \beta \\
& R_{31}=\cos \alpha \sin \beta \cos \gamma+\sin \alpha \sin \gamma \\
& R_{32}=\cos \alpha \sin \beta \sin \gamma-\sin \alpha \cos \gamma, \quad R_{33}=\cos \alpha \cos \beta
\end{aligned}
$$

$m$ は画像上の座標, $M$ は世界座標系上の座標, $P$ はカメラ の内部パラメータ, $R$ はカメラがレンズ中心に対する回転行 列， $\alpha, \beta, \gamma$ はそれぞれ $X, Y, Z$ 軸周りの回転角度である。 そして, 世界座標系と画像座標系の $Y$ 軸上の投影関係を $(2)$ 式で表すことができる。

$$
y=f \frac{X R_{21}+Y R_{22}+Z R_{23}}{X R_{31}+Y R_{32}+Z R_{33}}
$$

さらに(2)式において $Z$ 軸上で極值を取ることで, 消失線 の画像上の $y$ 座標がわかる。ここの消失線は消失点の水平線

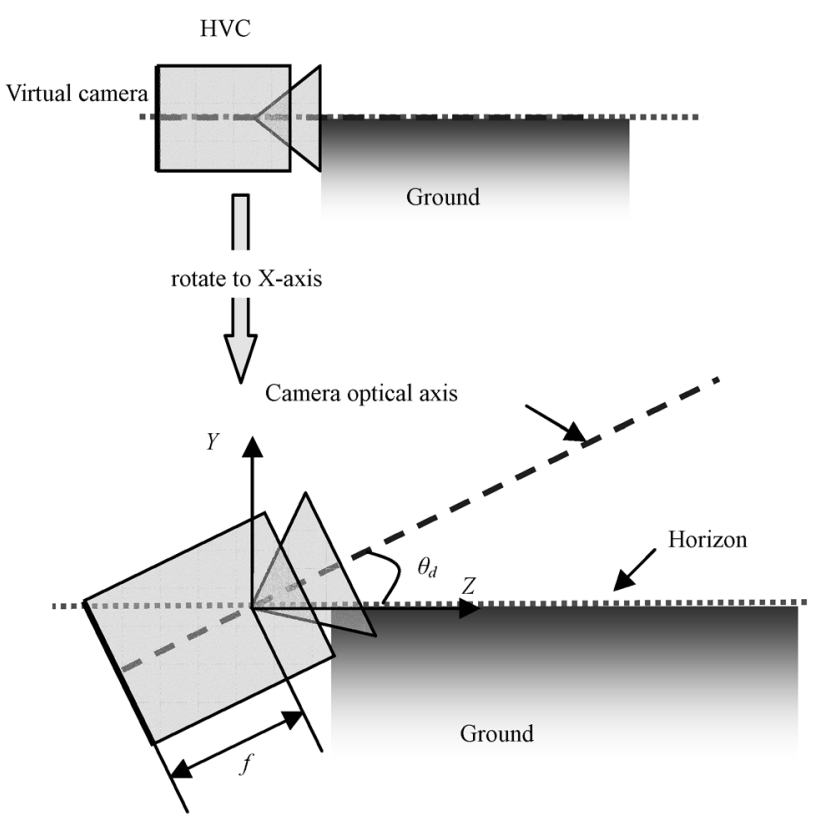

Fig. 1. Position of horizon in image

の高さを示す。(2)式で $Z$ の極值を取った結果を( 3 )式に示 す。

$$
\lim _{Z \rightarrow \infty} y=f \frac{R_{23}}{R_{33}}=f \frac{\sin \alpha \cos \beta}{\cos \alpha \cos \beta}
$$

従来の HVC システムでは, $R_{23}$ は 0 であるので, 消失線 は(3)式で $y=0$ と計算される, HVC ではカメラ光軸が地平 線を通るので, 消失線が地平線と一致することがわかる。 カメラが $X$ 軸周りに回転する角度を $\alpha=\theta_{d}$ とすると, 消失線 は(3)式で $y=f \tan \theta_{d}$ と計算される。図 1 に示寸ように, 回転 後の消失線と回転前の消失線の画像上の位置が $f \tan \theta_{d}$ に変 動するが， 3 次元位置が変わらないことがわかる。つまり， 回転後の消失線も地平線と一致する。図中の破線と点線は それぞれカメラ光軸と地平線の画像上の $y$ 座標を示す。

以上より, カメラのレンズ中心が地面上にあれば, カメ ラが回転しても地平線は画像上の座標は変わるが, 必ずカ メラレンズの中心を通り, 結像面に投影することがわかる。

〈3·2〉 一般化 HVCの提案 カメラが回転しても地平 線の場所は変わらない性質を利用して, より自由度の高い HVC システムが得られる。カメラのレンズの中心を地面に 設置すれば, カメラの角度に依存せずに HVC システムを構 築することができる。実際にカメラレンズの中心を地面に 設置するには, カメラを地面に埋め込む必要がある, これ は実現不可能である。そこで鏡を用いて, カメラレンズ中 心の虚像を地面上に置くように, 地面がカメラレンズ中心 と鏡の接地点の接線との角度を鏡との角度の 2 倍にする。 これによってカメラが回転しても, 地平線はいつも画像に 投影するように, 自由度の高い HVC システムが実現できる。 我々はこの自由度の高い HVC システムを一般化 HVC シス テムと呼ぶことにした。

実際にカメラの角度を $X$ 軸周りに適当に調整して作成し た一般化 HVC と従来 HVC を用いて撮影した。そして地面 


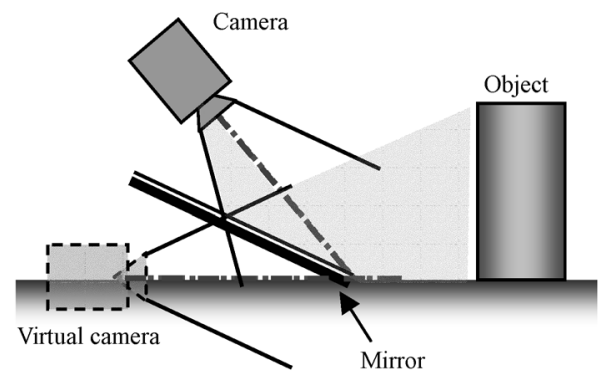

(a) $\mathrm{HVC}$

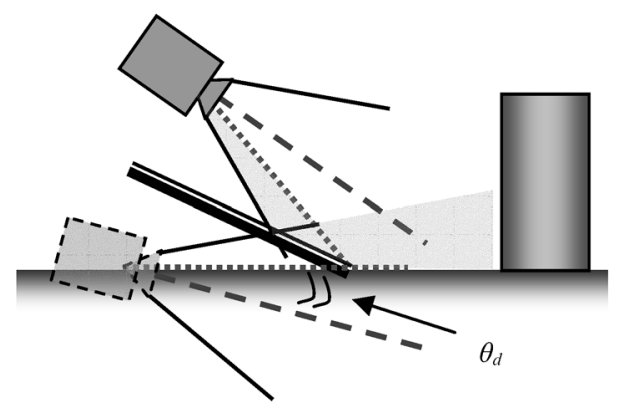

(b) GHVC

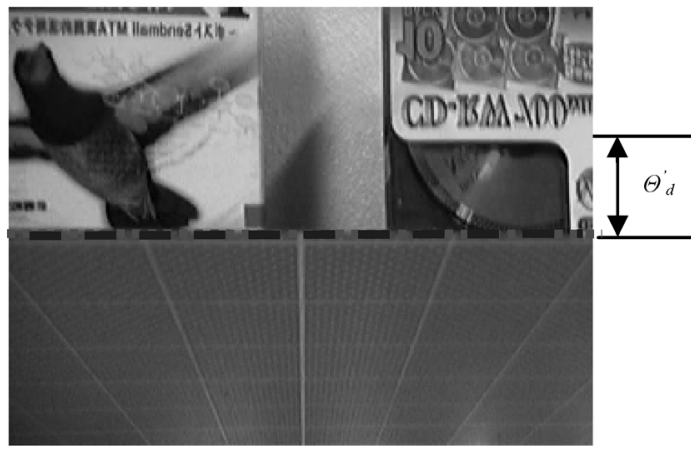

(c) Image from the HVC

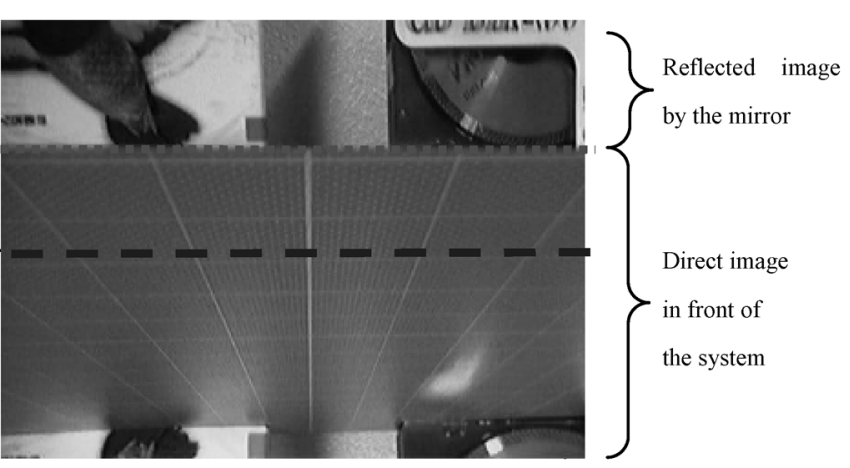

(d) Image from the generalized $\mathrm{HVC}\left(\Theta_{d}^{\prime}=f \tan \theta_{d}\right)$

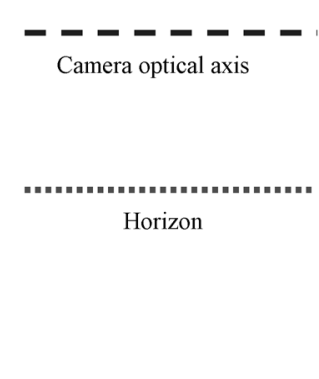

Fig. 2. Generalizing HVC and HVC

であることを分かりやすくするため，テーブルの上に格子 状パターンを置いてある。また，画像を分かりやすく表示 するため，カメラを通常とは上下逆に設置した，そのため 地平線の上部分が鏡の反射画像となり，また地平線の下部 分がシステム前方の直接画像となっている。図 2(a)(b)はそ れぞれ HVC と一般化 HVC のシステム構成を示す。図 2(c)(d) はそれぞれ HVC と一般化 HVC から得られた画像例である。 図に示すように，カメラレンズの中心が地面上にあれば, カメラ回転する場合, 地平線の画像上の $y$ 座標が $f \tan \theta_{d}$ 間隔 を変えるだけであり, 得られた反射画像の特徵は従来の HVC から得られた反射画像の特徵と変わらない。これによ って, カメラの角度を変更するだけで, 上方向に広視野を 持つ HVC システムの構築が可能となる。

\section{4. 物体検出}

〈4·1〉物体検出手法 一般的にカメラを前進移動し た場合，オプティカルフローは，画像中のある一点を中心 として放出される( ${ }^{(9)}$ 。一般化 HVC から得られる反射画像に おいて，システムを移動させることにより発生するオプテ イカルフローの放出点は, 必ず画像中の地平線上に位置す るという性質を持つ。さらにシステムが直進移動した場合 は，放出点は地平線の中心に存在し，また静止物体のオプ ティカルフローは放出点から外側へ放出される。したがっ て, 前進移動によるオプティカルフローの放出点を求める 必要はなく，オプティカルフローの検出は容易となる。オ プティカルフローを求めた際に，移動ベクトルが放出点か ら放出されなかった場合は，その部分は移動物体として認
識することができる。これを用いることで物体の距離計測 が可能であり，物体検出を行うことができる。

物体までの距離を検出する方法として，オプティカルフ ローを用いた ${ }^{(10)}$ 。カメラが前進移動したときに，カメラか ら物体までの距離が短い場合では物体は画像中を大きく移 動し，長い場合では物体はあまり移動しない。また物体が カメラの地平線から離れていると物体は大きく移動し, 地 平線付近では移動が少ない。この違いを用いて, カメラが 移動する前後での, 画像中の物体のオプティカルフローを 求め，それぞれの移動ベクトルの向きや大きさから物体ま での距離を計測することができる。本稿ではテンプレート マッチングを用いてオプティカルフローを求めた ${ }^{(11)}$ 。そし て得られたオプティカルフローの各移動ベクトルを用い て，物体までの距離を求める。

実際に物体検出するには, 一般化 HVC システムの反射画 像だけで行う。したがって，広い視野を観測するため，我々 はカメラの角度を調整し，画像全体を反射画像として使用 する。つまり, 図 3 のように虚像カメラの光軸と地面の角 度をカメラの上下の画角の半分角度で上向きに設定する。

図 3 のように移動後のカメラレンズの中心を世界座標系 の原点とした場合, カメラが直進移動したときの移動前と 移動後の 2 枚の反射画像を用いて, 反射画像中の物体の才 プティカルフローをテンプレートマッチングにより求め, それぞれの移動ベクトルの向きや大きさから物体までの距 離を計測する。カメラを理想的なピンホールカメラモデル と仮定すると，物体までの距離計測式は(4)，(5)式から求 まる。 


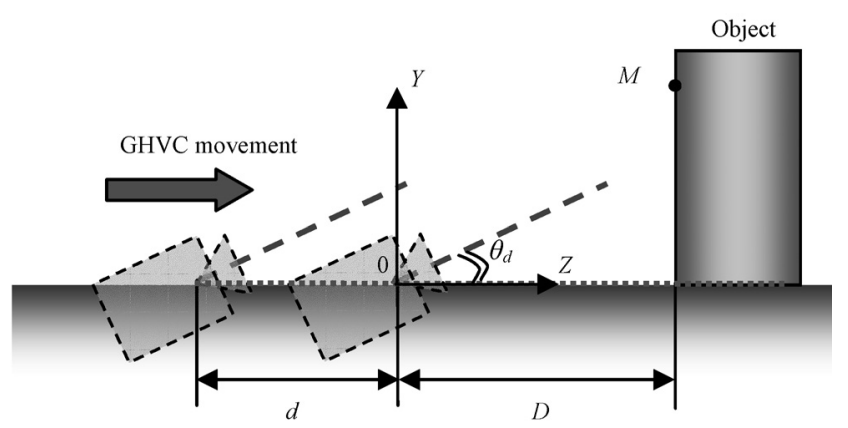

Fig. 3. Calculation of the distance to objects

$m_{r}=P R T M$

$m^{\prime}=P R M$

ここで

$$
\begin{aligned}
& m_{r}=\left(\begin{array}{c}
x_{r} \\
y_{r} \\
1
\end{array}\right), P=\left(\begin{array}{cccc}
f & 0 & 0 & 0 \\
0 & f & 0 & 0 \\
0 & 0 & 1 & 0
\end{array}\right) \\
& R=\left(\begin{array}{cccc}
1 & 0 & 0 & 0 \\
0 & \cos \theta_{d} & \sin \theta_{d} & 0 \\
0 & -\sin \theta_{d} & \cos \theta_{d} & 0 \\
0 & 0 & 0 & 1
\end{array}\right) \\
& m_{r}^{\prime}=\left(\begin{array}{c}
x_{r}^{\prime} \\
y_{r}^{\prime} \\
1
\end{array}\right), T=\left(\begin{array}{cccc}
1 & 0 & 0 & 0 \\
0 & 1 & 0 & 0 \\
0 & 0 & 1 & d \\
0 & 0 & 0 & 1
\end{array}\right), M=\left(\begin{array}{c}
X \\
Y \\
Z \\
1
\end{array}\right)
\end{aligned}
$$

(4), (5)式において, $m_{r}$ は移動前の反射画像中の座標值, $m_{r}^{\prime}$ は移動後の反射画像中の座標值であり，オプティカルフ ロー $m_{r} \rightarrow m_{r}^{\prime}$ を表す。また $P$ はピンホールカメラの内部パラ メータ, $R$ はカメラ光軸と地平線の角度 $\theta_{d}, \mathrm{HVC}$ の場合 $\theta_{d}=0$ 。 $T$ は一般化 $\mathrm{HVC}$ の前進移動距離 $d, M$ は実座標上のある点 $(X, Y, Z)$ である。

(4), (5)式から，実座標系空間上の座標を移動前と移動 後の画像 $y$ 軸上へ投影寸る投影変換式としてそれぞれ $(6)$ 式 と( 7 )式が得られる。

$$
\begin{aligned}
& y_{r}=f \frac{Y \cos \theta_{d}+Z \sin \theta_{d}+d \sin \theta_{d}}{-Y \sin \theta_{d}+Z \cos \theta_{d}+d \cos \theta_{d}} \\
& y_{r}^{\prime}=f \frac{Y \cos \theta_{d}+Z \sin \theta_{d}}{-Y \sin \theta_{d}+Z \cos \theta_{d}}
\end{aligned}
$$

さらに, (6), ( 7 )式から画像座標の実座標系空間への逆投 影変換( 8$)$, (9)式が得られる。

$$
Y=\frac{y_{r}\left(Z \cos \theta_{d}+d \cos \theta_{d}\right)-f\left(Z \sin \theta_{d}+d \sin \theta_{d}\right)}{f \cos \theta_{d}+y_{r} \sin \theta_{d}}
$$

$$
Y=\frac{y_{r}^{\prime} Z \cos \theta_{d}-f Z \sin \theta_{d}}{f \cos \theta_{d}+y_{r}^{\prime} \sin \theta_{d}}
$$

ここで $\mathrm{HVC}$ から物体までの垂直距離を $D$ とすると, $Z=D$ となる。そして(8), (9)式から(10)式のように距離計測式 が得られる。

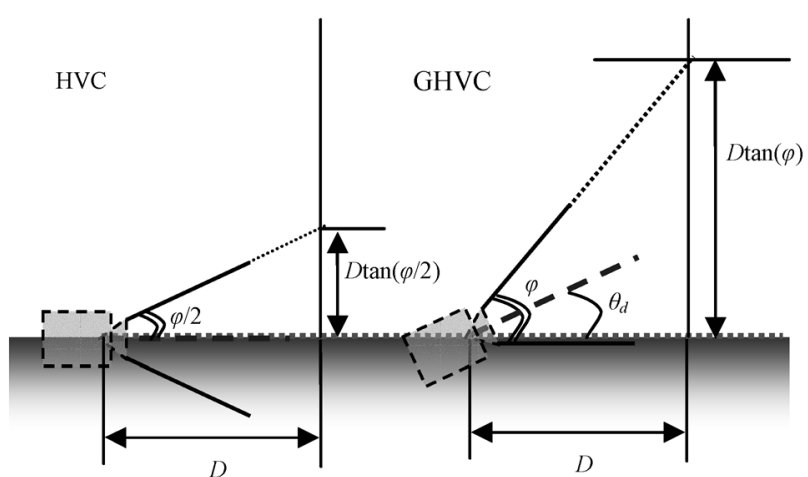

Fig. 4. Observation view of HVC and GHVC

$$
D=d \frac{\left(f \cos \theta_{d}+y_{r}^{\prime} \sin \theta_{d}\right)\left(y_{r} \cos \theta_{d}-f \sin \theta_{d}\right)}{f\left(y_{r}^{\prime}-y_{r}\right)}
$$

〈4·2〉計測精度についての考察＼cjkstart距離計測の精度は 様々な要因に関係するが, 例えば(10)式からシステムの前進 移動距離 $d$ が大きいほど距離計測精度が高くなる。また同 じ移動距離でも観測されるべクトルの長さ $\left|y_{r}^{\prime}-y_{r}\right|$ が長いほど 距離計測の精度も高くなる。次にカメラ光軸と地面の角度 $\theta_{d}$ を変え，観測視野が広くなった場合に計測精度が向上する ことを考察する。

実際にシステムが移動する際に, カメラの観測視野内の $Y$ 軸上に発生するべクトルは(11)式ように表すことができる。

$$
\begin{aligned}
& \Delta y=\left|y_{r}^{\prime}-y_{r}\right| \\
& =\left|f \frac{Y \cos \theta_{d}+Z \sin \theta_{d}}{-Y \sin \theta_{d}+Z \cos \theta_{d}}-f \frac{Y \cos \theta_{d}+Z \sin \theta_{d}+d \sin \theta_{d}}{-Y \sin \theta_{d}+Z \cos \theta_{d}+d \cos \theta_{d}}\right|
\end{aligned}
$$

ここで $\varphi$ をカメラの垂直視角とすると， $\theta_{d}$ はカメラ光軸 と地面の角度である。 HVC の場合, カメラ光軸が地平線上 を通るので, 反射画像の視角は $\varphi$ の半分 $\varphi / 2$ となる。カメラ が回転し $\theta_{d}$ を大きくすると, 反射画像の視角も大きくなる。 $\theta_{d}=\varphi / 2$ のとき, 反射画像の視角は HVC の場合の 2 倍となる。 これによって, 図 4 が示すように, カメラとの距離が $D$ に ある平面において, HVC は高さ $D \tan (\varphi / 2)$ まで観測できるに 対し, 一般化 HVC では, 最大高さ $D \tan \varphi$ まで観測すること ができる。

今回は, 反射画像内に発生するオプティカルフローのベ クトルの平均長と $\theta_{d}$ の関係から計測精度を調べることとし た。(11)式中のカメラとの距離 $Z$, システムの前進移動距離 $d$ を定数とした場合, $\theta_{d}$ を 0 から $\varphi / 2$ まで変化させると, 反 射画像の視角は $\varphi / 2$ から $\varphi$ まで変化することになる。 $\theta_{d}$ を 0.01 度刻みで変化させる度に, 反射画像の視角内で観測さ れるオプティカルフローのベクトルを(11)式で計算し， (12) 式でベクトルの平均を計算した。ただし， $Y$ は反射画像の視 角内に各刻み角度で観測される高さとし， $Y=D \tan \left(\varphi^{\prime}\right)$, $\varphi=\pi / 6, \varphi^{\prime}$ は各刻み角度, $N$ は刻みの個数である。すなわち $\theta_{d}$ を 0 から $\varphi / 2$ まで変化しながら得られた反射画像のオプテ 


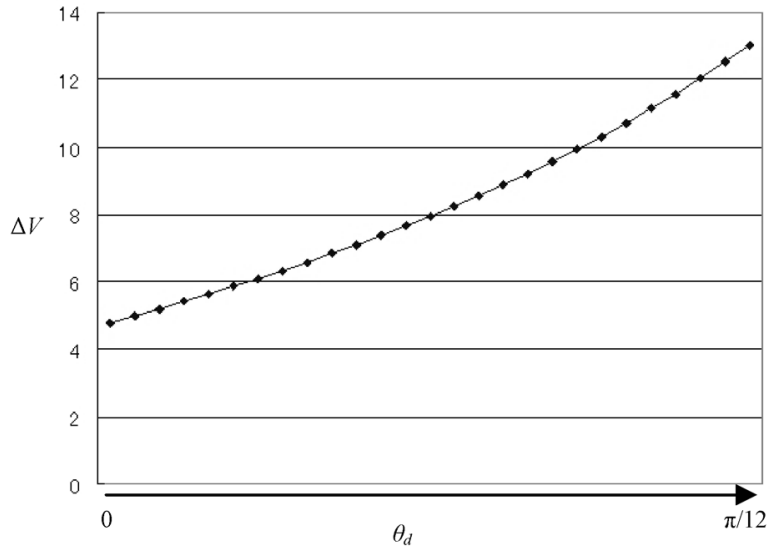

Fig. 5. Average length of optical flow

イカルフローのベクトルの平均長 $\Delta V$ を図 5 に示す。

$$
\Delta V=\frac{\sum_{\varphi^{\prime}=0}^{\frac{\varphi}{2}+\theta_{d}} y_{r}^{\prime}-y_{r}}{N}
$$

図 5 が示すように, 反射画像の視野が広がると, 得られ るオプティカルフローのベクトルの平均長も長くなること が分かる。従って，一般化 HVC が移動することで得られる ベクトルは HVC より総じて長くなり, 距離計測精度が向上 できると考えられる。

$\langle 4 \cdot 3\rangle$ 物体検出実験 $\langle 4 \cdot 1\rangle$ 節で得られた距離計測 式を用いて, 一般化 HVC から得られる濃淡画像を用いて物 体までの距離計測を行った。物体までの距離計測は, 先に 述べたように反射画像のみを用いて行った。実験は単純背 景において，テクスチャ模様を持つ平面をカメラから同じ 距離の位置に置き, カメラを $2 \mathrm{~cm}$ ずつ前進以移動させて, カメラから物体までの距離を $34 \mathrm{~cm}$ から $18 \mathrm{~cm}$ まで変化させ た。角度 $\theta_{d}=15$ 度, カメラの内部パラメータ $\mathrm{P}$ は, カメラレ ンズ歪みを無視した焦点距離 $f$ を用いた。カメラから得られ た 320×240pixel の画像を用いて, テンプレートマッチング によりオプティカルフローを求めた。確実にオプティカル フローの検出が可能となるように, テンプレートサイズを 9×9pixel とした。また本稿では, テンプレート中の明度情報 量を調心゙, 充分な明度情報量を有すると判定されたときの み, テンプレートマッチングを行い，テンプレートを作成 した座標とマッチングした座標から，物体の画像中でのオ プティカルフローを求めた。(10)式は画像の $y$ 座標の值のみ となっており, オプティカルフロー $\left(x_{r}, y_{r}\right) \rightarrow\left(x_{r}^{\prime}, y_{r}^{\prime}\right)$ が地平線付 近で縦方向に検出された場合, つまり, 差 $\left|y_{r} \rightarrow y_{r}^{\prime}\right|$ が小さい場 合は，視差が小さいために画像の量子化誤差の影響を大き く受け, 精度の高い距離計測は困難である。そこで地平線 付近のオプティカルフローを距離計測に使用しないことに した。また，オプティカルフローの延長線は必ず地平線の 中心を通るので，オプティカルフローの延長線と地平線の 交点が地平線の中心との距離が遠い場合, そのオプティカ ルフローは距離計算に使わないことにした。

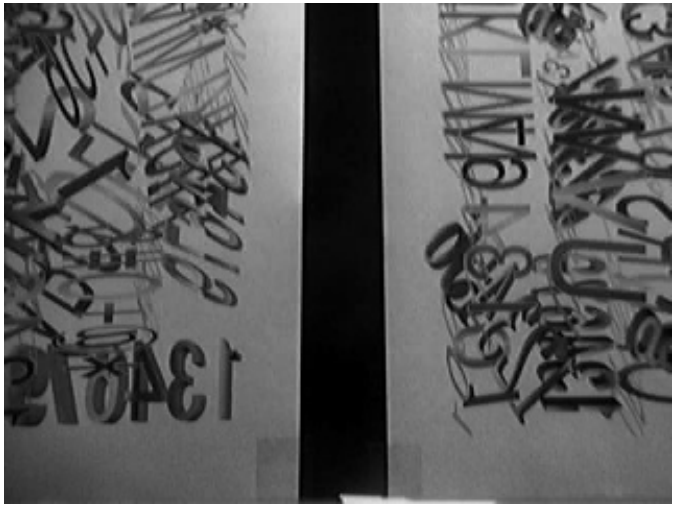

(a) $30 \mathrm{~cm}$ from camera

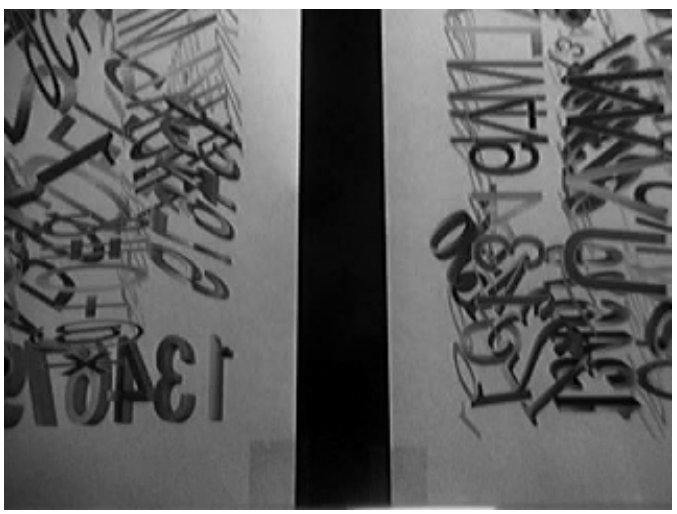

(b) $28 \mathrm{~cm}$ from camera

Fig. 6. Experimental image

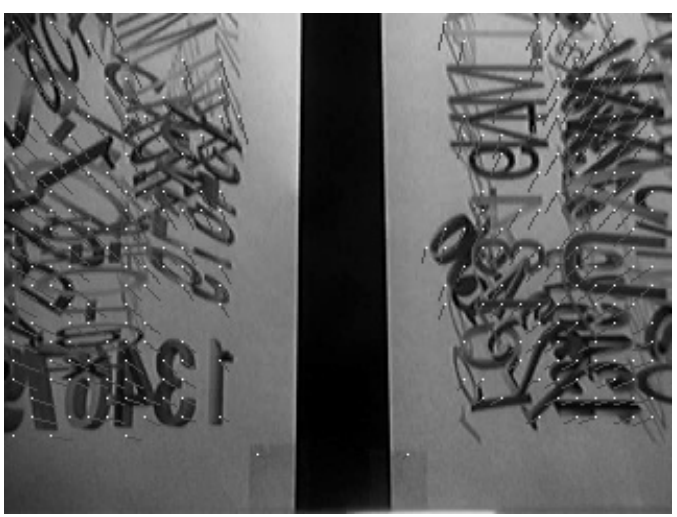

Fig. 7. Result of the detected optical flow

図 6 に実験画像を示す, また図 7 に物体とカメラの距離 が $28 \mathrm{~cm}$ の場合でのオプティカルフローの検出結果画像を 示す。X-Y 画像を用いて, 図 7 で検出された個々のオプテ イカルフローを使って得られた距離計測結果を図 8 示す, 図中の $x, y$ は画像のサイズを示し, $D$ は距離計測結果を示す。 同じ実験環境と方法で原理的に図 8 の上半分が観測されな い方式であるオリジナル HVC との比較を行った。ただし HVC の場合, カメラの回転がないので, 使用した距離計測 式は(10)式中の $\theta_{d}$ を 0 とした。その結果と一般化 HVC 用い た実験結果の比較を表 1 に示す。表 1 中の計測距離は, 一 
Table 1. Average error of distance measurement

\begin{tabular}{|c|c|c|c|c|c|c|c|c|c|}
\hline Actual distance & $34 \mathrm{~cm}$ & $32 \mathrm{~cm}$ & $30 \mathrm{~cm}$ & $28 \mathrm{~cm}$ & $26 \mathrm{~cm}$ & $24 \mathrm{~cm}$ & $22 \mathrm{~cm}$ & $20 \mathrm{~cm}$ & $18 \mathrm{~cm}$ \\
\hline Detected distance by GHVC & $33.09 \mathrm{~cm}$ & $31.89 \mathrm{~cm}$ & $30.66 \mathrm{~cm}$ & $28.56 \mathrm{~cm}$ & $26.61 \mathrm{~cm}$ & $24.79 \mathrm{~cm}$ & $22.61 \mathrm{~cm}$ & $21.12 \mathrm{~cm}$ & $19.02 \mathrm{~cm}$ \\
\hline Average error(GHVC) & $2.25 \mathrm{~cm}$ & $2.43 \mathrm{~cm}$ & $2.41 \mathrm{~cm}$ & $1.90 \mathrm{~cm}$ & $2.07 \mathrm{~cm}$ & $2.13 \mathrm{~cm}$ & $2.03 \mathrm{~cm}$ & $2.01 \mathrm{~cm}$ & $2.02 \mathrm{~cm}$ \\
\hline Detected distance by HVC & $32.07 \mathrm{~cm}$ & $29.37 \mathrm{~cm}$ & $28.12 \mathrm{~cm}$ & $27.79 \mathrm{~cm}$ & $25.01 \mathrm{~cm}$ & $22.86 \mathrm{~cm}$ & $22.08 \mathrm{~cm}$ & $20.37 \mathrm{~cm}$ & $17.62 \mathrm{~cm}$ \\
\hline Average error(HVC) & $2.92 \mathrm{~cm}$ & $3.28 \mathrm{~cm}$ & $2.93 \mathrm{~cm}$ & $2.50 \mathrm{~cm}$ & $2.96 \mathrm{~cm}$ & $2.01 \mathrm{~cm}$ & $2.40 \mathrm{~cm}$ & $2.18 \mathrm{~cm}$ & $2.18 \mathrm{~cm}$ \\
\hline
\end{tabular}

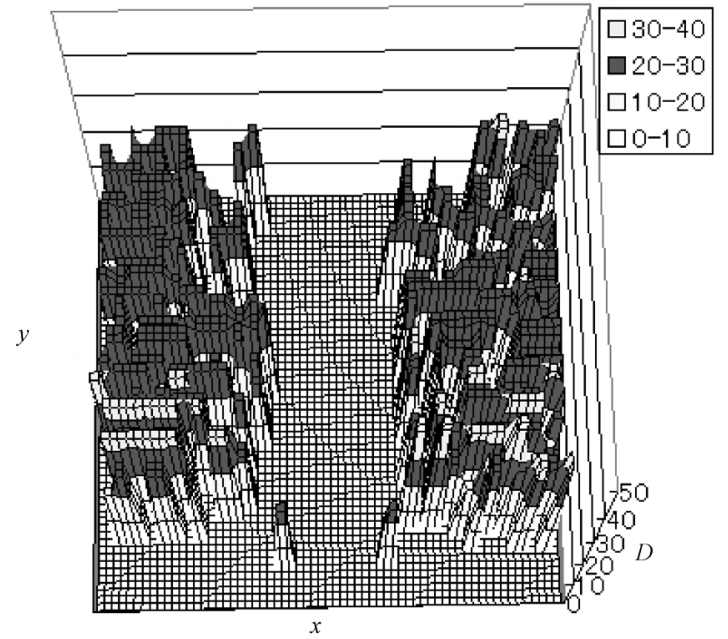

Fig. 8. Result of the detected distance

枚の画像中の個々のオプティカルフローから計算した距離 の平均であり，個々のオプティカルフローから計算された 距離とカメラから物体までの実際距離との差の絶対值をと り，その平均を距離計測誤差とした。

表 1 の結果より，一般化 HVC の方が視野が広がったこと によって，物体までの距離計測精度が向上することが可能 であることが確認できた。距離計測結果において，距離計 測に影響する原因として，次の二つが考えられる。

まずはシステム移動量の精度の影響が挙げられる。誤差 を持った前進の移動量を用いて距離計測をすることによっ て, 距離計測結果に移動量誤差の影響が含まれることで, 精度に影響すると考えられる。また画像の量子化䛊差も距 離計測精度に影響すると考えられる。これらの影響に対し, 画像解像度やシステムの移動距離を大きくすることで, 影 響を緩和することが可能である。

\section{5. まとめ}

本稿では, 従来の HVC システムの特徵を保ちながら, カ メラレンズの中心に存在する地平線を利用することで, よ り自由の高い一般化 HVC を提案した。これによって, カメ ラの角度を調整することで, より広い視野の HVC システム を得ることができた。また一般化 HVC システムの特性を利 用して, 物体までの距離計測法を考案した。そして, 直進 移動することでHVCよりより高い精度で距離を計測できる ことを示し，この手法が有効であることを確認した。

カメラ配置の自由度を高めたことで, 目的に合わせたカ メラ配置が可能となる。これによってより広い応用分野に
対して最適なシステムの構成が可能となる。例えば HVC に よる地面領域抽出法が提案されているが(8), 一般化 HVCを 用いてもカメラ角度を調整することで, より広い視野を観 測できるようになるとともに, 地面抽出も従来通り可能と なるシステムを構成できる。また, カメラシステムが自由 に移動しながら，物体までの距離を計算できるシステム Horizon View Camera-90 が提案されているが(7), これについ ても従来のシステムの特徴を保ちながら, 目的に合わせて 最適にカメラ配置を調整できると考えられる。これらにつ いて，今後も検討していく予定である。

一般化 HVC は，地面に設定できる小型システムであるこ とから, 小型ロボットにおける障害物検出や目標認識など に応用可能である。

物体までの距離計測実験では, 移動量誤差と画像量子化 誤差が距離計測結果に影響する。今後これについて改善す る予定である。例えば一般化 HVC システムから得られた画 像を log-polar 変換によって, 画像処理が容易で有効な性質 が現れる ${ }^{(6)}$ 。これは前に述べた一般化 HVC システムを直進 移動することで得られたオプティカルフローは必ず地平線 中心から放射状に流れる。これを log-polar 変換すると, 放 出されるオプティカルフローは静止物体に対しては常に上 方向に流れることになる。したがって, オプティカルフロ 一の検出がさらに容易になる。またオプティカルフローを 求める際の探索範囲が上方向のみとなることで, 計算時間 の削減が可能である。さらに log-polar 変換画像では, 物体 の拡大, 縮小を抑制することができる。そのため, オプテ イカルフロー検出精度が上がり, 距離計測精度が向上する 可能性がある。

(平成 19 年 3 月 19 日受付, 平成 19 年 7 月 26 日再受付)

\section{文献}

（1）富永昌治：「カラー画像の色分類と分割」, 情報処理学会論文誌, Vol.31, No.11, pp.1589-1598 (1990)

（2）平湯秀和・王 彩華・棚橋英樹 - 丹羽義典・山本和彦：「主曲率を用 いた確率的手法に基づく距離画像の分割」, 映像情報メディア学会 誌, Vol.56, No.4, pp.628-635 (2002)

(3) 藤吉弘亘・金出武雄:「複数物体の重なりを理解するレイヤー型検出 法」, 第 7 回画像センシングシンポジウム, pp.369-374 (2001)

（4）加藤博一・中澤篤志・井口征士 :「楕円体モデルを用いたリアルタイ 么人物追跡」, 情報処理学会論文誌, Vol.40, No.11, pp.4087-4096 (1999)

（5）川端敦・谷藤真也・諸岡泰男：「移動物体像の抽出技術」, 情報処 理学会論文誌, Vol.28, No.4, pp.395-402 (1987)

(6) A. Iwata, K. Kato, and K. Yamamoto : "The Detection of Obstacles by the Horizon View Camera”, IJIG, Vol.2, No.2, pp.331-341 (2002)

(7) 岩田彩見・加藤邦人・山本和彦：「直交カメラ系画像の協調を利用し た Horizon View Camera-90 の提案」, 電学論 C, Vol.123, No.12, 
pp.2085-2093 (2003-12)

（8）岩田彩見・加藤邦人・山本和彦：「カメラの光軸と地面を一致させた Horizon View Camera の光学特性とその実現」, 映像情報メディア学 会誌, Vol.58, No.9, pp.1291-1298 (2004)

( 9 ) B. K. P. Horn and B. G. Schunk : "Determining optical flow", Artificial Intelligence, Vol.17, pp.185-203 (1981)

(10) G. Adiv : "Determing 3-D Motion and Structure from Optical Flow Generated by Several Moving Objects", IEEE, PAMI, Vol.7, No.4, pp.384-401 (1985)

(11) A. K. Jain, Y. Zhong, and S. Lakshmanan : "Object Matching Using Deformable Templates”, IEEE, PAMI, Vol.18, No.3, pp.267-278 (1996)

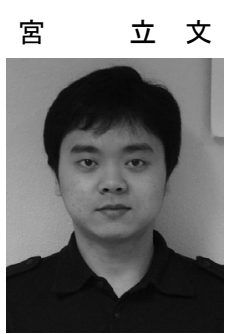

（非会員） 1979 年 7 月 19 日生。2006 年岐阜大 学工学部応用情報学科卒業。現在, 同大学院工 学研究科応用情報学専攻博士前期課程に在学 中。コンピュータビジョンの研究に従事。
山 本 和 彦 (正員) 1944 年 6 月 20 日生。1971 年東京電

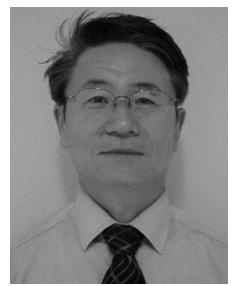
機大学大学院修士課程修了。同年, 通産省電子 技術総合研究所入所。1996 年から現在, 岐阜大 学工学部応用情報学科教授。主に画像解析, パ ターン認識の研究に従事。工博。

加 藤 邦人 (非会員) 1971 年 2 月 18 日生。1996 年中京大

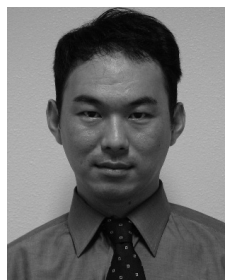

学大学院情報科学研究科修士課程修了。同年, 同大学院博士課程。現在岐阜大学工学部助手。 画像処理, 特に Hough 変換による直線検出とそ の応用の研究に従事。情報科学博士 